\title{
Potential of Plant Species for Bioremediation of Soils Applied WITH IMIDAZOLINONE HERBICIDES ${ }^{1}$
}

\author{
Potencial de Espécies Vegetais para Fitorremediação de Solos com Herbicidas do Grupo das \\ Imidazolinonas
}
GALON, L. ${ }^{2}$, LIMA, A.M. ${ }^{3}$, GUIMARÃES, S. ${ }^{3}$, BELARMINO, J.G. ${ }^{3}$, BURG, G.M. ${ }^{3}$, CONCENÇO, G. ${ }^{4}$, BASTIANI, M.O. ${ }^{3}$, BEUTLER, A.N. ${ }^{3}$, ZANDONA, R.R. ${ }^{3}$, and RADÜNZ, A.L. ${ }^{2}$

\begin{abstract}
Imidazolinone herbicides present physicochemical characteristics that allow them to persist longer in environment, with increased chances of soil and water contamination, as well as carryover effects on subsequent crops. Phytoremediation is shown as a promising technique to decontaminate soils polluted by herbicides. The aim of this study was to assess the potential of some winter grown species in removing residuals from soils contaminated with imazethapyr + imazapic and imazapic + imazapyr, using pre-emergence to control weeds in summer grown rice fields. The experiment was conducted in a completely randomized design, with four replications. All species were subjected to herbicide application at different doses. Imazethapyr + imazapic and imazapyr + imazapic were applied at doses of 0.0, 1.0 and $2.0 \mathrm{~L} \mathrm{ha}^{-1}$, and 0.0, 140 and $280 \mathrm{~g} \mathrm{ha}^{-1}$, respectively, in pre-emergence of the species. Brassica napus and Festuca arundinaceae are not tolerant to herbicides, with $100 \%$ of phytotoxicity (plant death) for all doses assessed. The herbicide imazapyr + imazapic proved to be less selective, causing the highest phytotoxicity in the species tested. The most tolerant species to the herbicides was Vicia sativa, which may be the most suitable one for phytoremediation programs in areas contaminated with imazethapyr + imazapic and imazapyr + imazapic.
\end{abstract}

Keywords: bioremediation, ALS inhibitors, Vicia sativa.

RESUMO - Os herbicidas pertencentes ao grupo quimico das imidazolinonas apresentam características fisico-quimicas que lhes permitem persistir no ambiente por longos periodos. Assim, objetivou-se com este trabalho avaliar o potencial de espécies cultivadas como pastagens, cobertura verde no inverno e/ ou produtoras de grãos em remediar solos contaminados com imazethapyr + imazapic e imazapyr + imazapic, usados para o controle de plantas daninhas em lavouras de arroz irrigado. Para isso, o experimento foi conduzido em delineamento inteiramente casualizado com quatro repetições. As espécies Lolium multiflorum, Lotus corniculatus, Trifolium repens, Festuca arundinaceae, Vicia sativa e Brassica napus foram submetidas à aplicação de herbicidas em diferentes doses. Os herbicidas imazethapyr + imazapic e imazapyr + imazapic foram aplicados nas doses de 0,0, 1,0 e 2,0 L ha-1 e de 0,0, 140 e $280 \mathrm{~g} \mathrm{ha}^{-1}$, respectivamente, em pré-emergência das espécies. Os resultados demonstram que B. napus e $\boldsymbol{F}$. arundinaceae não são tolerantes aos herbicidas, apresentando $100 \%$ de fitotoxicidade (morte das plantas), para todas as doses avaliadas. O herbicida imazapyr + imazapic demonstrou ser menos seletivo, tendo ocasionado os maiores indices de fitotoxicidade nas espécies testadas. V. sativa foi mais tolerante aos herbicidas podendo ser a mais indicada para os programas de fitorremediação em áreas contaminadas com imazethapyr + imazapic e imazapyr + imazapic.

Palavras-chave: biorremediação de solos, inibidores de ALS, Vicia sativa.

Recebido para publicação em 13.3.2014 e aprovado em 22.7.2014.

2 Universidade Federal da Fronteira Sul, Erechim-RS, Brasil, <leandro.galon@uffs.edu.br>; ${ }^{3}$ Universidade Federal do Pampa Itaqui-RS, Brasil; ${ }^{4}$ Embrapa Agropecuária Oeste (CPAO), Dourados-MS, Brasil. 


\section{INTRODUCTION}

The southern region of Brazil is responsible for $53.8 \%$ of planted rice area in the country, especially the state of Rio Grande do Sul, which cultivates $86 \%$ of this area (CONAB, 2014). Thus, it is perceived that rice cultivation has economic and social importance to this state, because it generates income and many direct and indirect jobs in the supply chain of that culture.

Among the factors affecting the productivity and profitability of rice crops, there is the competition with weeds. Among the weeds, there is red rice as the most problematic, causing losses of up to $20 \%$ in grain yield, if no control method is adopted (Marchesan et al., 2004). Besides being considered a difficult to control species, because it possesses morphological and physiological similarities with cultivated rice, herbicides traditionally used to control red rice have been shown to be ineffective (Santos et al., 2007; Streck et al., 2008).

Among the alternatives to control red rice, stands out in the present the use of the Clearfield ${ }^{\circledR}$ system, wherein the rice crops are tolerant to the herbicide application of the chemical group of imidazolinones, which allows efficient control of this weed species. However, the herbicides used in this system have physical and chemical characteristics that allow them to persist in the environment for long periods of time (Vencill, 2002), larger than those of the rice cycle and may result in carryover to subsequent crops (Pinto et al., 2009), or be leached and consequently contaminate surface and groundwater.

To alleviate the problems caused by the persistence of herbicides in soil, the technique of phytoremediation was proposed (Santos et al., 2004; Pires et al., 2005). This technique consists in decontaminating soil or water using plants and their associated microbiota (Santos et al., 2010), being efficient in decontaminating soils with presence of herbicides such as tebuthiuron (Pires et al., 2005), trifloxysulfuron-sodium (Santos et al., 2004) and picloram (Procópio et al., 2008). However, information is scarce on the use of Phytoremediator species in soils contaminated by the imidazolinone chemical group, used to control red rice in irrigated rice fields of Rio Grande do Sul.

Further studies are needed that address the selection of species able to degrade or immobilize the waste in soil or plant. However, one should avoid the use of species that have difficult handling after its use as soil Phytoremediator and, if possible, select the ones that promote other benefits to the ground, such as the ones that can be used in green manures, fodder or even as producing grain (Procópio et al., 2005).

Given the above, noting the premise of species that may, in addition to carrying the phytoremediation effect, have other purposes within the property, such as serving as pasture, soil cover for the adoption of direct planting or even for grain production, this research was done using Lolium multiflorum, Lotus corniculatus, Trifolium repens, Festuca arundinaceae, Vicia sativa and Brassica napus.

The objective of this study was to assess the potential of cultivated species such as pasture, green cover in winter and/or grain producer, remediating contaminated soils with imazethapyr + imazapic and imazapyr + imazapic used for weed control in flooded rice soils.

\section{MATERIALS AND METHODS}

The experiment was conducted in a greenhouse at Universidade Federal do Pampa, Campus Itaqui-RS, between October and December 2011. The experimental units consisted of plastic pots with a capacity of $8 \mathrm{dm}^{3}$, filled with soil from areas of rice cultivation, classified as Haplic Plinthosol (Embrapa, 2006). It is worth noting that the area where the soil was collected had no history of herbicide application - a relevant fact to not influence the results of the experiment.

The correction of soil fertility was performed according to the technical recommendations for irrigated rice crop (SOSBAI, 2010). The chemical and physical characteristics of the soil were: $\mathrm{pH}$ in water of 4.8; $\mathrm{MO}=4.7 \mathrm{dag} \mathrm{kg}^{-1} ; \mathrm{P}=6.8 \mathrm{mg} \mathrm{dm}^{-3}$; $\mathrm{K}=48 \mathrm{mg} \mathrm{dm}^{-3} ; \mathrm{Al}^{3+}=0.5 \mathrm{cmol}_{\mathrm{c}} \mathrm{dm}^{-3} ; \mathrm{Ca}^{2+}=$ $4.76 \mathrm{cmol}_{\mathrm{c}} \mathrm{dm}^{-3} ; \mathrm{Mg}^{2+}=1.03 \mathrm{cmol}_{\mathrm{c}} \mathrm{dm}^{-3} ; \mathrm{CTC}(\mathrm{t})$ $=6.4 \mathrm{cmol}_{\mathrm{c}} \mathrm{dm}^{-3} ; \mathrm{CTC}(\mathrm{T})=15.6 \mathrm{cmol}_{\mathrm{c}} \mathrm{dm}^{-3}$; 
$\mathrm{H}+\mathrm{Al}=9.7 \mathrm{cmol}_{\mathrm{c}} \mathrm{dm}^{-3} ; \mathrm{SB}=60.59 \mathrm{cmol}_{\mathrm{c}} \mathrm{dm}^{-3} ;$ $\mathrm{V}=38 \%$; and clay $=20 \%$. The species were sown to identify the possible potential to tolerate herbicides imazethapyr + imazapic and imazapyr + imazapic and subsequently employ them in phytoremediation programs in areas that are contaminated by these products.

The experimental design was completely randomized, in a $2 \times 3$ factorial arrangement, with four replications. In factor $A$, were allocated the herbicides imazethapyr + imazapic e imazapyr + imazapic, respectively $\mathrm{Only}^{\mathbb{R}}$ and $\mathrm{Kifix}^{\mathbb{R}}$; and in B were applied the doses of $0.0,1.0$ and $2.0 \mathrm{~L} \mathrm{ha}^{-1}$ and of $0.0,140.0$ and $280.0 \mathrm{~g} \mathrm{ha}^{-1}$, respectively, in pre-emergence of the species. The species that were tested: L. multiflorum (Italian ryegrass or annual ryegrass), L. corniculatus (Bird's-foot Trefoil), T. repens (white clover or Dutch clover), $F$. arundinaceae (tall fescue), $V$. sativa (common vetch or tare) and $B$. napus (rapeseed).

Herbicides were applied to the soil using precision backpack sprayer, equipped with two spray tips of the TT 110.02 series with a spray volume of $150 \mathrm{~L} \mathrm{ha}^{-1}$. The sowing of the species was done one day before herbicide application; after germination thinning was held, leaving four plants per pot. For good plant growth, irrigation was performed daily in the experimental units, keeping the humidity around $80 \%$ of field capacity.

The variables assessed at 60 days after emergence of the species were phytotoxicity, height, number of tillers of Gramineae or true grasses and/or branches of other families (Legumes and/or Brassica), stalk and/or stem diameter, leaf area and dry matter of the aerial part of the plants. Phytotoxicity was determined by visual assessment by two reviewers, with scores between zero (no injury) to 100\% (complete plant death), as proposed by SBCPD (1995). Height $(\mathrm{cm})$ of plants was measured using a graduated scale, from close to the ground until the last fully expanded leaves. The number of tillers of Gramineae or true grasses and/or branches of other families (legumes and/or Brassica) was determined by counting. The diameter $(\mathrm{mm})$ of the stalk and/or stem was measured with a digital caliper at $5 \mathrm{~cm}$ of the soil surface. Leaf area $\left(\mathrm{cm}^{2}\right.$ per pot) was determined with an electronic leaf area meter model Liquor (3100); then the material was placed in paper bags and put to drying in a forced air oven at a temperature of $60 \pm 5{ }^{\circ} \mathrm{C}$, until reaching a constant weight to determine the dry weight of shoots (g per pot).

Data were subjected to analysis of variance by $\mathrm{F}$ test; when significant, the Tukey test $(\mathrm{p} \leq 0.05)$ was applied.

\section{RESULTS AND DISCUSSION}

The results show distinct responses of species assessed against the residual phytotoxic effect of imazethapyr + imazapic and imazapyr + imazapic in different doses in which herbicides were applied (Table 1). The sensitivity of species to herbicide and to the applied dose is mainly due to the intrinsic characteristics of these, i.e., each responds differently to the effects of the applied products. The same was noticed by Madalão et al. (2012), when assessing potential remedial of species Crotalaria juncea, Canavalia ensiformis and Cajanus cajan, with regard to application of doses of sulfentrazone herbicide.

Table 1 - Phytotoxicity (\%) at 60 days after emergence of the winter species submitted to the application of doses of imazethapyr + imazapic and imazapyr + imazapic in preemergence

\begin{tabular}{|l|c|c|c|}
\hline \multirow{3}{*}{ Species } & \multicolumn{3}{|c|}{ Herbicides } \\
\cline { 2 - 4 } & Doses & $\begin{array}{c}\text { Imazethapyr } \\
\text { imazapic }\end{array}$ & $\begin{array}{c}\text { Imazapyr }+ \\
\text { imazapic }\end{array}$ \\
\hline \multirow{3}{*}{ L. multiflorum } & 0 & $0.0 \mathrm{Aa}^{1 /}$ & $0.0 \mathrm{Aa}$ \\
\cline { 2 - 4 } & 1 & $48.3 \mathrm{Bb}$ & $80.0 \mathrm{Ba}$ \\
\hline \multirow{3}{*}{ L. corniculatus } & 2 & $65.0 \mathrm{Cb}$ & $100.0 \mathrm{Ca}$ \\
\cline { 2 - 4 } & 0 & $0.0 \mathrm{Aa}$ & $0.0 \mathrm{Aa}$ \\
\cline { 2 - 4 } T. repens & 2 & $25.0 \mathrm{Bb}$ & $90.3 \mathrm{Ba}$ \\
\hline \multirow{3}{*}{ F. arundinaceae } & 0 & $50.0 \mathrm{Cb}$ & $100.0 \mathrm{Ba}$ \\
\cline { 2 - 4 } & 1 & $0.0 \mathrm{Aa}$ & $0.0 \mathrm{Aa}$ \\
\cline { 2 - 4 } & 2 & $36.7 \mathrm{Bb}$ & $97.3 \mathrm{Ba}$ \\
\cline { 2 - 4 } V. sativa & 1 & $100.7 \mathrm{Cb}$ & $100.0 \mathrm{Ba}$ \\
\cline { 2 - 4 } & 2 & $100.0 \mathrm{Ba}$ & $100.0 \mathrm{Ba}$ \\
\hline \multirow{3}{*}{ B. napus } & 0 & $0.0 \mathrm{Aa}$ & $0.0 \mathrm{Ba}$ \\
\cline { 2 - 4 } & 2 & $13.3 \mathrm{Bb}$ & $41.7 \mathrm{Ba}$ \\
\hline Overall average & 0 & $23.3 \mathrm{Bb}$ & $53.3 \mathrm{Ca}$ \\
\hline CV (\%) & 1 & $95.3 \mathrm{Ba}$ & $100.0 \mathrm{Ba}$ \\
\cline { 2 - 4 } & 2 & $98.7 \mathrm{Ba}$ & $100.0 \mathrm{Ba}$ \\
\hline
\end{tabular}

${ }^{1 /}$ Means followed by the same capital letters in the column, comparing doses within each species, and smaller lower case in the line, comparing herbicides together for each dose, do not differ by Tukey test at $5 \%$ probability. 
Imazapyr + imazapic caused a greater percentage of phytotoxicity compared to imazethapyr + imazapic, having been, in average, higher in 58.7, 53.3, 82.1 and $159.6 \%$, respectively for $L$. multiflorum, $L$. corniculatus, $T$. repens and $V$. sativa (Table 1 ). The dose tested influenced the phytotoxicity to the species, and differences for L. multiflorum, $L$. corniculatus and $T$. repens were noticed when was applied the mixture of imazethapyr + imazapic and in the species L. multiflorum and $V$. sativa for imazapyr + imazapic, with the other species, already in the lowest dose tested, having caused a mortality rate higher than $90 \%$ (Table 1). It was also observed that imazapyr + imazapic caused the death of $83 \%$ of the species in the highest doses, in comparison to imazethapyr + imazapic, which caused 33\%.

Galon et al. (2012), when working with imazethapyr + imazapic, imazapyr + imazapic, imazethapyr and imazapic applied in different doses on the rice cultivar Puitá Inta-CL and rice-weedy, also observed the greatest phytotoxic effects of the herbicide imazapyr + imazapic in relation to the others, which corroborates the results found in this study. It is possible to associate the differences noticed between imazethapyr + imazapic and imazapyr + imazapic to the components of both mixtures, since imazapyr (525 g i.a. $\left.\mathrm{kg}^{-1}\right)$ + imazapic (175 g i.a. $\mathrm{kg}^{-1}$ ), besides showing a higher concentration of imazapic in its formulation, has the active compound imazapyr, replacing imazethapyr, found in the mixture of imazethapyr $\left(75\right.$ g i.a. $\left.\mathrm{L}^{-1}\right)+$ imazapic ( $25 \mathrm{~g}_{\text {i.a. }} \mathrm{L}^{-1}$ ). Thus, the persistence in soil of the two commercially formulated mixtures of imazethapyr + imazapic and imazapyr + imazapic can be variable, depending on the dose, making the residual herbicide activity entailing different levels of injuries in susceptible crops grown in succession and/or rotation with Clearfield ${ }^{\circledR}$ rice (Santos et al., 2014).

The species $B$. napus and $F$. arundinaceae did not tolerate the application of the two doses of imazethapyr + imazapic (1.0 and $\left.2.0 \mathrm{~L} \mathrm{ha}^{-1}\right)$, as well as $T$. repens for imazapyr + imazapic (140.0 and $280.0 \mathrm{~g} \mathrm{ha}^{-1}$ ), where phytotoxicity was observed above $95 \%$ or even in some situations, the plants later died (Table 1).
As for $V$. sativa, for the two herbicides tested at both doses smaller phytotoxicity were found, compared to the other species assessed (Table 1).

In relation to plant height (Table 2), it was found, among the species tested, that L. multiflorum showed increased tolerance to imazapyr + imazapic in dose 1 , and $V$. sativa, in doses 1 and 2. It is noteworthy that, in other species, plant death occurred. Pinto et al. (2009) noticed a reduction in plant height as there was increase of the dose of imazethapyr + imazapic applied to control of red rice in irrigated rice.

The results demonstrate that application of $1,0 \mathrm{~L} \mathrm{ha}^{-1}$ of imazethapyr + imazapic did not differ from the untreated control (dose 0) of the herbicide regarding the height of plants of the species $L$. corniculatus, $T$. repens and $V$. sativa (Table 2). For other species, plant mortality was observed or they stopped the growth in stature. Thus, the results found in this study and by other researchers (Santos et al., 2007; Pinto et al., 2009; Santos et al., 2014) show that the

Table 2 - Height of plants (cm) at 60 days after emergence of the winter species submitted to the application of doses of imazethapyr + imazapic and imazapyr + imazapic in preemergence

\begin{tabular}{|c|c|c|c|}
\hline \multirow[b]{2}{*}{ Species } & \multicolumn{3}{|c|}{ Herbicides } \\
\hline & Doses & $\begin{array}{c}\text { Imazethapyr + } \\
\text { imazapic }\end{array}$ & $\begin{array}{c}\text { Imazapyr + } \\
\text { imazapic }\end{array}$ \\
\hline \multirow{3}{*}{ L. multiflorum } & 0 & $36.1 \mathrm{Aa}^{1 /}$ & $38.3 \mathrm{Aa}$ \\
\hline & 1 & $24.9 \mathrm{Ba}$ & $25.8 \mathrm{Ba}$ \\
\hline & 2 & $9.5 \mathrm{Ca}$ & $0.0 \mathrm{Cb}$ \\
\hline \multirow{3}{*}{ L. corniculatus } & 0 & $8.3 \mathrm{Aa}$ & $7.6 \mathrm{Aa}$ \\
\hline & 1 & $6.4 \mathrm{Aa}$ & $0.0 \mathrm{Bb}$ \\
\hline & 2 & $5.4 \mathrm{Aa}$ & $0.0 \mathrm{Bb}$ \\
\hline \multirow{3}{*}{ T. repens } & 0 & $12.5 \mathrm{Aa}$ & $12.0 \mathrm{Aa}$ \\
\hline & 1 & $10.0 \mathrm{Aa}$ & $0.0 \mathrm{Bb}$ \\
\hline & 2 & $4.6 \mathrm{Ba}$ & $0.0 \mathrm{Bb}$ \\
\hline \multirow{3}{*}{ F. arundinaceae } & 0 & $29.5 \mathrm{Aa}$ & $29.3 \mathrm{Aa}$ \\
\hline & 1 & $0.0 \mathrm{Ba}$ & $0.0 \mathrm{Ba}$ \\
\hline & 2 & $0.0 \mathrm{Ba}$ & $0.0 \mathrm{Ba}$ \\
\hline \multirow{3}{*}{ V. sativa } & 0 & $29.4 \mathrm{Aa}$ & $29.6 \mathrm{Aa}$ \\
\hline & 1 & $29.2 \mathrm{Aa}$ & $19.5 \mathrm{Bb}$ \\
\hline & 2 & $25.6 \mathrm{Ba}$ & $22.1 \mathrm{Bb}$ \\
\hline \multirow{3}{*}{ B. napus } & 0 & $23.9 \mathrm{Aa}$ & $23.6 \mathrm{Aa}$ \\
\hline & 1 & $0.0 \mathrm{Ba}$ & $0.0 \mathrm{Ba}$ \\
\hline & 2 & $0.0 \mathrm{Ba}$ & $0.0 \mathrm{Ba}$ \\
\hline \multicolumn{2}{|l|}{ Overall average } & \multicolumn{2}{|c|}{12.95} \\
\hline \multicolumn{2}{|l|}{$\mathrm{CV}(\%)$} & \multicolumn{2}{|c|}{14.29} \\
\hline
\end{tabular}

1/ Means followed by the same capital letters in the column, comparing doses within each species, and smaller lower case in the line, comparing herbicides together for each dose, do not differ by Tukey test at $5 \%$ probability. 
use of imazethapyr + imazapic and of imazapyr + imazapic in the Clearfield ${ }^{\circledR}$ system of yielding may result in increase of herbicide residues in soil and end up derailing the cultivation of susceptible crops in succession to irrigated rice.

It is worth noting that the stoppage of the plant growth (height) is one of the characteristics that demonstrate the sensitivity of the species to the action of the group of imidazolinone herbicides (Pinto et al., 2009). The application of $200 \mathrm{~g} \mathrm{ha}^{-1}$ of imazethapyr for weed control in soybean, caused stoppage of growth of maize plants sown six months after the soybean harvest, when compared with the control without application (Gazziero et al., 1997).

The number of tillers of Gramineae or true grasses or branches of other families (legumes and/or Brassica) decreased in practically all treatments except $V$. sativa, which showed no differentiation between doses and herbicides imazethapyr + imazapic and imazapyr + imazapic, and of $L$. corniculatus only for imazapyr + imazapic, when applying doses 1 or 2 (Table 3). These results show that after the use of mixtures of imazethapyr + imazapic and imazapyr + imazapic, it is necessary to pay attention to deploying the successor culture, because not all species coexist with the residual of these herbicides.

The stalk and/or stem diameter of the species suffered greater reductions in the residual effect of imazapyr + imazapic, having only $V$. sativa as the species which suffered negative effect when two doses of the two herbicides were applied (Table 4). It was noticed that the use of imazethapyr + imazapic did not cause reduction of the diameter of the stem of L. corniculatus in all the doses applied. It is worth considering that the stem and/or stalk diameter is directly related to the support of leaves and inflorescences of cultures and also acts as a structure for the storage of reserves that can be used by plants as a source for a particular drain (Carmo et al., 2012), directly influencing plant lodging.

The results for leaf area (Table 5) show similar behavior to the height variable of the plant (Table 2). At the application of the mixture imazapyr + imazapic, only $V$. sativa (doses 1
Table 3 - Number of tillers of Gramineae or true grasses and/or ramifications of legumes or Brassica at 60 days after emergence of the winter species submitted to the application of doses of imazethapyr + imazapic and imazapyr + imazapic in pre-emergence

\begin{tabular}{|c|c|c|c|}
\hline \multirow[b]{2}{*}{ Species } & \multicolumn{3}{|c|}{ Herbicides } \\
\hline & Doses & $\begin{array}{c}\text { Imazethapyr + } \\
\text { imazapic }\end{array}$ & $\begin{array}{c}\text { Imazapyr + } \\
\text { imazapic }\end{array}$ \\
\hline \multirow{3}{*}{ L. multiflorum } & 0 & $73.3 \mathrm{Aa}^{1 /}$ & $76.0 \mathrm{Aa}$ \\
\hline & 1 & $45.3 \mathrm{Ba}$ & $46.7 \mathrm{Ba}$ \\
\hline & 2 & $40.0 \mathrm{Ba}$ & $0.0 \mathrm{Cb}$ \\
\hline \multirow{3}{*}{ L. corniculatus } & 0 & $14.7 \mathrm{Aa}$ & $14.7 \mathrm{Aa}$ \\
\hline & 1 & $10.7 \mathrm{Aa}$ & $0.0 \mathrm{Bb}$ \\
\hline & 2 & $10.6 \mathrm{Aa}$ & $0.0 \mathrm{Bb}$ \\
\hline \multirow{3}{*}{ T. repens } & 0 & $48.0 \mathrm{Aa}$ & $46.7 \mathrm{Aa}$ \\
\hline & 1 & $24.0 \mathrm{Ba}$ & $0.0 \mathrm{Bb}$ \\
\hline & 2 & $16.0 \mathrm{Ba}$ & $0.0 \mathrm{Bb}$ \\
\hline \multirow{3}{*}{ F. arundinaceae } & 0 & $28.0 \mathrm{Aa}$ & $29.3 \mathrm{Aa}$ \\
\hline & 1 & $0.0 \mathrm{Ba}$ & $0.0 \mathrm{Ba}$ \\
\hline & 2 & $0.0 \mathrm{Ba}$ & $0.0 \mathrm{Ba}$ \\
\hline \multirow{3}{*}{$V$. sativa } & 0 & $21.3 \mathrm{Aa}$ & $20.0 \mathrm{Aa}$ \\
\hline & 1 & $21.3 \mathrm{Aa}$ & 17.3 Aa \\
\hline & 2 & $17.3 \mathrm{Aa}$ & $16.0 \mathrm{Aa}$ \\
\hline \multirow{3}{*}{ B. napus } & 0 & $36.0 \mathrm{Aa}$ & $36.0 \mathrm{Aa}$ \\
\hline & 1 & $0.0 \mathrm{Ba}$ & $0.0 \mathrm{Ba}$ \\
\hline & 2 & $0.0 \mathrm{Ba}$ & $0.0 \mathrm{Ba}$ \\
\hline \multicolumn{2}{|l|}{ Overall average } & \multicolumn{2}{|c|}{20.20} \\
\hline \multicolumn{2}{|l|}{$\mathrm{CV}(\%)$} & \multicolumn{2}{|c|}{25.47} \\
\hline
\end{tabular}

and 2) and L. multiflorum (dose 1) showed tolerance to the residual effect of the herbicide. However, $V$. sativa in dose 2 reduced approximately $50 \%$ of the leaf area, in relation to the treatment that did not receive herbicide.

The mixture of imazethapyr + imazapic, in general, had a higher leaf area to that found using the imazapyr + imazapic (Table 5). It was observed for $L$. multiflorum a reduction of 159.65 and $571.37 \%$ of the leaf area when comparing the dose and twice as much the recommended dose of imazethapyr + imazapic, respectively, with the control without application. Also for imazethapyr + imazapic, reductions in the leaf area were not seen only for $V$. sativa in the applied doses of this herbicide (Table 5). It is believed that the tolerance of species to herbicides of the chemical groups of imidazolinone and sulfonylurea in general is associated with increased metabolism of the product or differential metabolism in relation to the prone ones (Vargas et al., 1999). 
Table 4 - Stalks and/or stems diameter ( $\mathrm{mm})$ at 60 days after emergence of the winter species submitted to the application of doses of imazethapyr + imazapic and imazapyr + imazapic in pre-emergence

\begin{tabular}{|l|c|c|c|}
\hline \multirow{3}{*}{ Species } & \multicolumn{3}{|c|}{ Herbicides } \\
\cline { 2 - 4 } & Doses & $\begin{array}{c}\text { Imazethapyr }+ \\
\text { imazapic }\end{array}$ & $\begin{array}{c}\text { Imazapyr }+ \\
\text { imazapic }\end{array}$ \\
\hline \multirow{3}{*}{ L. multiflorum } & 0 & $13.0 \mathrm{Aa}^{1 /}$ & $12.8 \mathrm{Aa}$ \\
\cline { 2 - 4 } & 1 & $8.3 \mathrm{Ba}$ & $8.2 \mathrm{Ba}$ \\
\cline { 2 - 4 } L. corniculatus & 2 & $7.4 \mathrm{Ba}$ & $0.0 \mathrm{Cb}$ \\
\cline { 2 - 4 } & 0 & $3.4 \mathrm{Aa}$ & $3.7 \mathrm{Aa}$ \\
\cline { 2 - 4 } & 2 & $2.4 \mathrm{Aa}$ & $0.0 \mathrm{Ba}$ \\
\hline \multirow{3}{*}{ T. repens } & 0 & $2.4 \mathrm{Aa}$ & $0.0 \mathrm{Ba}$ \\
\cline { 2 - 4 } & 1 & $4.6 \mathrm{Aa}$ & $4.4 \mathrm{Aa}$ \\
\hline \multirow{3}{*}{ F. arundinaceae } & 2 & $1.0 \mathrm{Aa}$ & $0.0 \mathrm{Bb}$ \\
\cline { 2 - 4 } & 0 & $8.8 \mathrm{Aa}$ & $0.0 \mathrm{Bb}$ \\
\cline { 2 - 4 } & 1 & $0.0 \mathrm{Ba}$ & $0.7 \mathrm{Aa}$ \\
\hline \multirow{3}{*}{ V. sativa } & 2 & $0.0 \mathrm{Ba}$ & $0.0 \mathrm{Ba}$ \\
\hline \multirow{2}{*}{ B. napus } & 0 & $5.2 \mathrm{Aa}$ & $5.15 \mathrm{Aa}$ \\
\cline { 2 - 4 } & 1 & $5.0 \mathrm{Aa}$ & $4.9 \mathrm{Aa}$ \\
\hline Overall average & 2 & $4.4 \mathrm{Aa}$ & $4.2 \mathrm{Aa}$ \\
\hline CV (\%) & 0 & $30.0 \mathrm{Aa}$ & $29.5 \mathrm{Aa}$ \\
\cline { 2 - 4 } & 2 & $0.0 \mathrm{Ba}$ & $0.0 \mathrm{Ba}$ \\
\hline
\end{tabular}

1/ Means followed by the same capital letters in the column, comparing doses within each species, and smaller lower case in the line, comparing herbicides together for each dose, do not differ by Tukey test at $5 \%$ probability.

It should be stressed that the leaf area influences the selection of species for phytoremediation purposes of herbicides, because it is related to photosynthesis and thus to the accumulation of photoassimilates, but also on the ability of shading weeds, improving use as pasture and/or ground cover.

The shoot dry mass (MSPA), presented in Table 6, shows that the species suffer smaller reductions when sprayed with imazethapyr + imazapic compared with the use of imazapyr + imazapic. Among the species assessed, L. multiflorum, L. corniculatus and T. repens showed a decrease of about 80,75 and $85 \%$ when submitted to the highest dose of imazethapyr + imazapic. As for $V$. sativa, for the same herbicide, was the species less affected, with a decrease of about $20 \%$ in MSPA.

Imazapyr + imazapic caused a reduction of more than $400 \%$ in the accumulation of MSPA of the L. multiflorum when $140 \mathrm{~g} \mathrm{ha}^{-1}$ of the herbicide were applied (dose 1), when
Table 5 - Leaf area $\left(\mathrm{cm}^{2}\right.$ per pot) at 60 days after emergence of the winter species submitted to the application of doses of imazethapyr + imazapic and imazapyr + imazapic in preemergence

\begin{tabular}{|l|c|c|c|}
\hline \multirow{2}{*}{ Species } & \multicolumn{3}{|c|}{ Herbicides } \\
\cline { 2 - 4 } & Doses & $\begin{array}{c}\text { Imazethapyr } \\
\text { imazapic }\end{array}$ & $\begin{array}{c}\text { Imazapyr }+ \\
\text { imazapic }\end{array}$ \\
\hline \multirow{3}{*}{ L. multiflorum } & 0 & $1381.0 \mathrm{Aa}^{\mathrm{I}}$ & $1374.8 \mathrm{Aa}$ \\
\cline { 2 - 4 } & 1 & $865.0 \mathrm{Ba}$ & $168.4 \mathrm{Bb}$ \\
\cline { 2 - 4 } & 2 & $241.7 \mathrm{Ca}$ & $0.0 \mathrm{Cb}$ \\
\hline \multirow{3}{*}{ T. reprniculatus } & 0 & $252.1 \mathrm{Aa}$ & $245.9 \mathrm{Aa}$ \\
\cline { 2 - 4 } & 1 & $146.7 \mathrm{Ba}$ & $0.0 \mathrm{Bb}$ \\
\cline { 2 - 4 } & 2 & $131.3 \mathrm{Ba}$ & $0.0 \mathrm{Bb}$ \\
\hline \multirow{3}{*}{ F. arundinaceae } & 0 & $410.5 \mathrm{Aa}$ & $420.5 \mathrm{Aa}$ \\
\cline { 2 - 4 } & 1 & $152.9 \mathrm{Ba}$ & $0.0 \mathrm{Bb}$ \\
\cline { 2 - 4 } & 2 & $70.8 \mathrm{Ca}$ & $0.0 \mathrm{Bb}$ \\
\cline { 2 - 4 } V. sativa & 1 & $838.4 \mathrm{Aa}$ & $835.7 \mathrm{Aa}$ \\
\cline { 2 - 4 } & 2 & $0.0 \mathrm{Ba}$ & $0.0 \mathrm{Ba}$ \\
\hline \multirow{2}{*}{ B. napus } & 0 & $202.1 \mathrm{Aa}$ & $200.5 \mathrm{Ba}$ \\
\cline { 2 - 4 } & 2 & $157.7 \mathrm{Aa}$ & $146.7 \mathrm{Bb}$ \\
\hline Overall average & 0 & $1682.6 \mathrm{Aa}$ & $101.4 \mathrm{Cb}$ \\
\hline CV (\%) & 1 & $0.0 \mathrm{Ba}$ & $1679.1 \mathrm{Aa}$ \\
\cline { 2 - 4 } & 2 & $0.0 \mathrm{Ba}$ & $0.0 \mathrm{Ba}$ \\
\hline
\end{tabular}

1/ Means followed by the same capital letters in the column, comparing doses within each species, and smaller lower case in the line, comparing herbicides together for each dose, do not differ by Tukey test at $5 \%$ probability.

comparing with the control without application (dose 0), having caused the death of the plants in dose 2. For $V$. sativa was also noticed a decrease of about $50 \%$ of the accumulation of MSPA in the presence of imazapyr + imazapic, when treated with a higher dose of the product. Similar results were found by Pinto et al. (2009), where the dry matter of the Italian ryegrass or annual ryegrass plant, sown in succession with rice, was negatively influenced when the dose of 50 or $100 \mathrm{~g} \mathrm{ha}^{-1}$ of imazethapyr + imazapic was increased. As for Villa et al. (2006), when working with cultures sensitive to herbicides of the imidazolinone chemical group, they observed that the dry mass of $L$. multiflorum, sown in succession with rice Clearfield $^{\circledR}$, was not changed by the residual activity of imazethapyr + imazapic.

In general, when comparing herbicides together, applied at the recommended dose or double dose, it was observed that the mixture of imazapyr + imazapic showed greater injury 
to plants of all assessed species and variables, except in treatments where plants died while being treated by the two mixtures studied (Tables 1, 2, 3, 4, 5 and 6). Santos et al. (2014) also noticed a higher activity of the mixture of imazapyr + imazapic, when comparing to imazethapyr + imazapic, and attributed this to the components of the two mixtures, as already explained.

The ability of phytoremediation of persistent herbicides in soil, by the species $L$. multiflorum and $V$. sativa para imazapyr + imazapic and L. multiflorum, T. repens and $V$. sativa for imazathapyr + imazapic is due to phytostimulation and rhizodegradation of these plants. This is because plants release exudates in rhizospheric environment, thus favoring the proliferation of microorganisms - those which will be responsible for the degradation of the herbicide compounds. Stimulation to microbial activity, promoted by the release of substances, is what characterizes, in some plants, the rhizospheric suitability for phytoremediation

Table 6 - Shoot dry mass - MSPA (g per pot) at 60 days after emergence of the winter species submitted to the application of doses of imazethapyr + imazapic and imazapyr + imazapic in pre-emergence

\begin{tabular}{|l|c|c|c|}
\hline \multirow{2}{*}{ Species } & \multicolumn{3}{|c|}{ Herbicides } \\
\cline { 2 - 4 } & Doses & $\begin{array}{c}\text { Imazethapyr } \\
\text { imazapic }\end{array}$ & $\begin{array}{c}\text { Imazapyr } \\
\text { imazapic }\end{array}$ \\
\hline \multirow{3}{*}{ L. multiflorum } & 0 & $18.2 \mathrm{Aa}^{1}$ & $18.2 \mathrm{Aa}$ \\
\cline { 2 - 4 } & 1 & $7.1 \mathrm{Ba}$ & $3.3 \mathrm{Bb}$ \\
\cline { 2 - 4 } L. corniculatus & 2 & $3.2 \mathrm{Ca}$ & $0.0 \mathrm{Cb}$ \\
\cline { 2 - 4 } & 0 & $2.0 \mathrm{Aa}$ & $2.0 \mathrm{Aa}$ \\
\cline { 2 - 4 } & 1 & $0.7 \mathrm{Ba}$ & $0.0 \mathrm{Bb}$ \\
\hline \multirow{3}{*}{ T. repens } & 2 & $0.5 \mathrm{Ba}$ & $0.0 \mathrm{Bb}$ \\
\hline \multirow{3}{*}{ F. arundinaceae } & 0 & $4.0 \mathrm{Aa}$ & $3.8 \mathrm{Aa}$ \\
\cline { 2 - 4 } & 2 & $1.8 \mathrm{Ba}$ & $0.0 \mathrm{Bb}$ \\
\hline \multirow{3}{*}{ V. sativa } & 0 & $0.6 \mathrm{Ca}$ & $0.0 \mathrm{Bb}$ \\
\cline { 2 - 4 } & 2 & $6.4 \mathrm{Aa}$ & $6.5 \mathrm{Aa}$ \\
\hline \multirow{2}{*}{ B. napus } & 0 & $0.0 \mathrm{Ba}$ & $0.0 \mathrm{Ba}$ \\
\cline { 2 - 4 } & 1 & $11.8 \mathrm{Ba}$ & $0.0 \mathrm{Ba}$ \\
\cline { 2 - 4 } & 2 & $10.4 \mathrm{Ba}$ & $6.7 \mathrm{Ab}$ \\
\hline Overall average & 0 & $11.5 \mathrm{Aa}$ & $11.3 \mathrm{Aa}$ \\
\hline CV (\%) & 1 & $0.0 \mathrm{Ba}$ & $0.0 \mathrm{Ba}$ \\
\cline { 2 - 4 } & 2 & $0.0 \mathrm{Ba}$ & $0.0 \mathrm{Ba}$ \\
\hline
\end{tabular}

1/ Means followed by the same capital letters in the column, comparing doses within each species, and smaller lower case in the line, comparing herbicides together for each dose, do not differ by Tukey test at $5 \%$ probability. of soils (Santos et al., 2004; Procópio et al., 2005). In this sense, the main route of degradation of imidazolinone occurs mainly by the action of aerobic microorganisms, being practically nil under anaerobic conditions (Mangels, 1991), promoting a high persistence of herbicides imazethapyr and imazapic for hydromorphic soils with intoxication verified in non-tolerant rice sown 361 days after application (Villa et al., 2006).

It may also be noticed that the species assessed in this study have been used as winter cover crops, forage for livestock and/or grain yield in crop rotation systems in Rio Grande do Sul. Thus, the possibility of dual purpose magnifies the chance to use them in programs of phytoremediation of soils contaminated with imazapyr + imazapic and imazethapyr + imazapic.

Based on the results of this study, it is concluded that the assessed species show differences in tolerance to the application of imazethapyr + imazapic and imazapyr + imazapic and also regarding these herbicides dose applied in pre-emergence. B. napus and $F$. arundinaceae were the ones less tolerant to the herbicides and, therefore, do not show a potential for phytoremediation of the soils treated with imazethapyr + imazapic and imazapyr + imazapic in any dose applied. $L$. corniculatus and $T$. repens were at intermediate levels of tolerance to the herbicides. The most tolerant species to the herbicides was $V$. sativa, and may be indicated for the phytoremediation programs in areas that have received an application of imazethapyr + imazapic and imazapyr + imazapic, both in the dose as in the double doses applied, followed by $L$. multiflorum, which has tolerated imazethapyr + imazapic in both doses. Among the herbicides tested, imazapyr + imazapic showed a higher toxic effect on species than imazethapyr + imazapic.

\section{ACKNOWLEDGMENT}

To Conselho Nacional de Desenvolvimento Científico e Tecnológico (National Council for Scientific and Technological Development) (CNPq), by the financial support (process n. 483564/2010-9) for carrying out the research. 


\section{LITERATURE CITED}

CARMO, M. S. et al. Doses e fontes de nitrogênio no desenvolvimento e produtividade da cultura de milho doce (Zea mays convar. saccharata var. rugosa).

Biosci.J., v. 28, n.1, p. 223-231, 2012.

COMPANHIA NACIONALDEABASTECIMENTO-

CONAB. Arroz. Disponível em: $<$ http://

www.conab.gov.br/conteudos.php? $\mathrm{a}=1252 \& \mathrm{t}=2>$.

Acesso em: 16 jun. 2014.

EMPRESA BRASILEIRA DE PESQUISA

AGROPECUÁRIA-EMBRAPA. Sistema brasileiro de classificação de solos. Brasília: 2006.306 p.

GALON, L. et al. Eficácia e seletividade de herbicidas do grupo das imizadolinonas aplicados em arroz irrigado.

R. Bras.Herbic., v. 11, n. 3, p. 284-295, 2012.

GAZZIERO, D. L. P. et al. Persistência dos herbicidas imazaquin e imazethapyr no solo e os efeitos sobre plantas de milho e pepino. Planta Daninha, v. 15, n. 2, p. 162-169, 1997.

MADALÃO, J. C. et al. Uso de leguminosas na fitorremediação de solo contaminado com sulfentrazone. Pesq.Agropec.Trop., v. 42, n. 4, p. 390-396, 2012.

MANGELS, G. Behavior of the imidazolinone herbicides in soil: a review of the literature. In: SHANER, D. L.; O'CONNOR, S. L. (Ed.). The imidazolinone herbicides. Boca Raton: CRC Press, 1991.p. 191-209.

MARCHESAN, E. Controle do arroz-vermelho. In: GOMES, A. S.; MAGALHÃES JÚNIOR, A. M. (Ed.). Arroz irrigado no Sul do Brasil. Brasília: Embrapa Informação, 2004. p. 547-577.

PINTO, J. J. O. et al. Atividade residual de (imazethapyr + imazapic) sobre azevém anual (Lolium multiflorum), semeado em sucessão ao arroz irrigado, sistema Clearfield ${ }^{\circledR}$. Planta Daninha, v. 27, n. 3, p. 609-619, 2009.

PIRES, F. R. et al. Inferências sobre atividade rizosférica de espécies com potencial para fitorremediação do herbicida tebuthiuron. R. Bras. Ci. Solo, v. 29, n. 4, p. 627-634, 2005.

PROCÓPIO, S. O. et al. Potencial de espécies vegetais para a remediação do herbicida trifloxysulfuron-sodium. Planta Daninha, v. 23, n. 1, p. 9-16, 2005.
PROCÓPIO, S. O. et al. Fitorremediação de solo contaminado com picloram por capim-pé-de-galinhagigante (Eleusine coracana). R. Bras. Ci. Solo, v. 32, n. 6, p. $2517-2524,2008$.

SANTOS, E. A. et al. Seletividade do herbicida trifloxysulfuron sodium para fins de fitorremediação.

R. Ceres, v. 51, n. 293, p. 129-141, 2004.

SANTOS, F. M. et al. Controle químico de arrozvermelho na cultura do arroz irrigado. Planta Daninha, v. 25, n. 2 , p. $405-412,2007$.

SANTOS, E. A. et al. Atividade rizosférica de solo tratado com herbicida durante processo de remediação por Stizolobium aterrimum. Pesq. Agropec. Trop, v. 40, n. 1,p. 1-7, 2010.

SANTOS, L.O. et al. Carryover effect of imidazolinone herbicides for crops following rice. Am. J.Plant Sci., v. 5, n. 8 , p. 1049-1058, 2014.

SOCIEDADE BRASILEIRA DA CIÊNCIA DAS PLANTAS DANINHAS - SBCPD. Procedimentos para instalação, avaliação e análise de experimentos com herbicidas. Londrina: $1995.42 \mathrm{p}$.

\section{SOCIEDADE SUL-BRASILEIRADEARROZ} IRRIGADO - SOSBAI. Arroz irrigado:

Recomendações técnicas da pesquisa para o Sul do Brasil. Bento Gonçalves: 2010. 188 p.

STRECK, N. A. et al. Comparação de parâmetros de crescimento e de desenvolvimento de dois biótipos de arroz vermelho com genótipos de arroz irrigado.

Bragantia, v. 67, n. 2, p. 349-360, 2008.

VARGAS, L. et al. Resistência de plantas daninhas a herbicidas. Viçosa, MG: Universidade Federal de Viçosa, 1999. $131 \mathrm{p}$.

VENCILL, W. L. et al. (Ed). Herbicide handbook. 8.ed. Lawrence: Weed Science Society of America, 2002. $493 \mathrm{p}$.

VILLA, S. C. C. et al. Arroz tolerante a imidazolinonas: controle do arroz-vermelho, fluxo gênico e efeito residual do herbicida em culturas sucessoras nãotolerantes. Planta Daninha, v. 24, n. 4, p. 761-768, 2006. 